From the Anat. Tabor. of Prof. H. SETO, Tohoku University, Sendai.

\title{
Fine Structure and Innervation of Penis in Dog.
}

\author{
大㓌䒝の微組構造と神経分布。
}

\author{
Hisashi SHIMIZU 清 水 寿.
}

[Received May 2, 1954]

Many authors in the past have spoken on the histology on the innervation of external genitals of man and animals, throwing much light on the problem, but in respect to the penis, the studies by RETZIUS (1890), SCLA VUNOS (1894), DOGIEL (1893), FERRARINI (1906), MÚLLER and DAHL (1912). OHMORI (1924), MATSUDA (1935) etc. have failed in achieving noteworthy results, owing to the imperfection of staining methods hitherto available. However, the study by ENDO (1954) of this laboratory with the penis in pig as objective published recently is well worth of special mention. Also the study by SETO (1942) on the innervation, especially the sensory innervation of the penis of human embryos must be mentioned with honor.

The author of this paper had the opportunity of studying the innervation, and the sensory innervation in particular, of the penis of dogs. The materials used were fixed in $10 \%$ neutral formol for a long time, cut into $30-40 \mu$ frozen sections and stained with SETO's silver impregnation in general use in this laboratory. The observations obtained from these preparations were compared with those obtained by ENDO (1954) upon pig penis in the main, but also with those of TELLO (1932) on human, goat and rat clitorides and the entirely dependable observations of YAMADA (1951) on human clitoris. The conclusions arrived at are outlined hereunder.

\section{Individual Observations.}

There have been very few, if any, studies on the innervation of canine penis in the past, except one brief description thereof by OHMORI (1924). According to him, no corpuscular termination is found in the penis of a dog, all the sensory terminations therein being in the form of his so-called free endings, and these in a much smaller number than those in other animals.

Since the histological image of the structure of an organ stands in a very close relation with the innervation, especially, with the sensory innervation, of that organ, I will preface my detailed descirption of the nerves in a canine penis with a word on the histological image 
thereof. On the other hand, as there are many points in the histology of this part still left unclarified, I believe that my following discourse on the histology of a canine penis is not without general interest and benefit.

The penis of a dog is not essentially different from the same organ of man or other animals in that it contains the urethra and shows cavernous formation indispensable to copulative organs, but there are also several points of variation in histological structure peculiar to the canine penis, so that its innervation is also different from that in man and other animals, as may be easily inferred.

In the foremost part of the canine penis, as shown in Figs 1 and

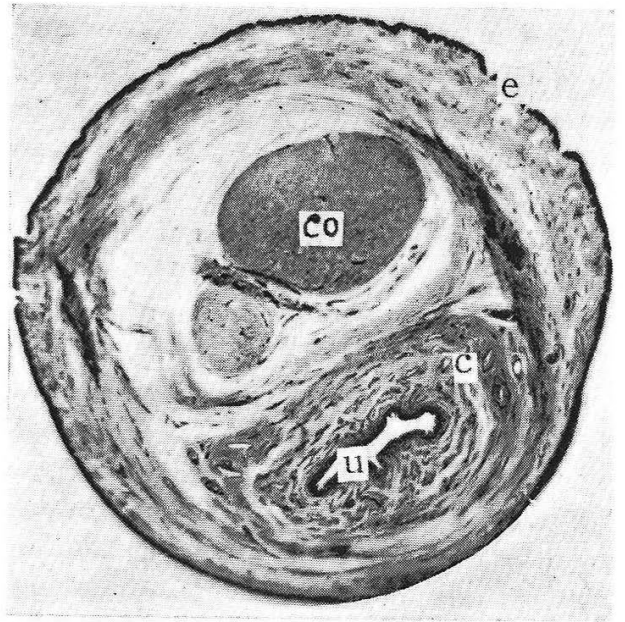

Fig. 1. A transversal picture through the distal part of a canine glans penis. u urethra; - corpus cavernosum urethrae; co specific connective tissue column; e epithelium glandis. SETO's impregnation, photo $\times 10$. 2 , the elongated so-called penis bone is found on the dorsal side of the corpus cavernosum urethrae. The corpora cavernosa penis of both sides disappear upon reaching the glans penis and in their stead a special so-called corpus cavernosum glandis or bulbus glandis is formed enveloping the penis bone and the corpus cavernosum urethrae. This corpus touches the inside of the comparatively loosely arranged annular connective tissue layer beneath the cylindrically elongated lamina propria glandis and extends to the vicinity of the tip of the glans penis.

At the tip of the glans, we find an ill-developed cavernous formation looking very different from the corpus cavernosum glandis, which SCHMALTZ (1911) has named the "Spitzenkappe" or the tip cap.

The periosteum of the penis bone is very strongly developed and its outer longitudinally arranged collagenous connective tissue layer lines the dorsal and lateral tunica albuginea of the corpus cavernosum urethrae lying on the ventral side of the penis bone, fortifying the albuginea formation. The urethra is composed of a mucous membrane much poorer in folds than in human urethra, its epithelium consisting of stratified columnar epithelium of 5-6 cells layer and occasional stratified flat 


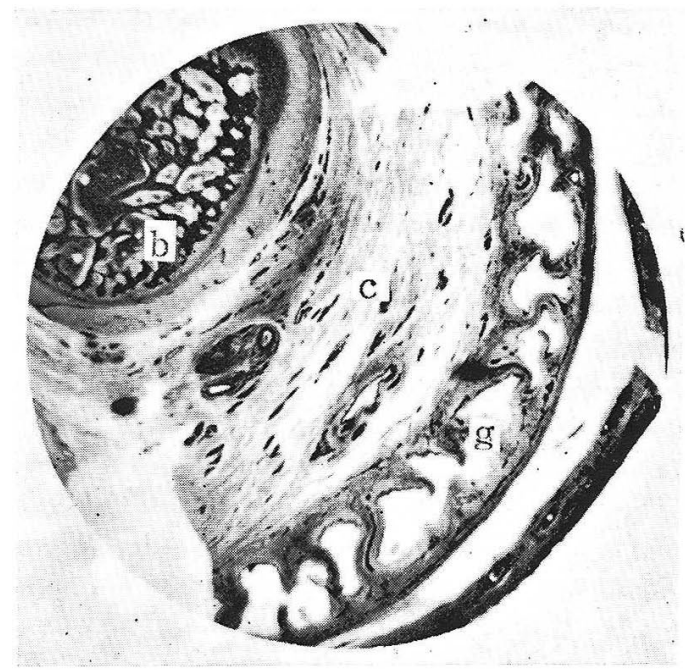

Fig. 2. A transversal picture through the basal part of a canine glans penis. b os penis with a strong periosteum; c circular layer of connective tissue; g tubular corpus cavernosum glandis. Same staining, photo $\times 10$.

epithelium. As was the case with the tip of the urethra in pig (ENDO, 1954), no urethral glands, as observable in human urethra, were ever found in the canine urethra. The lamina propria is a thin layer of minute fibrous connective tissue, containing a few minute veins and capillaries.

Around the propria urethrae and rather clearly standing out of it we find the corpus cavernosum urethrae, enwrapped in a tunica albuginea composed of annular connective tissue fibres. This cavernous body is better dereloped than in man, is full of numerous longitudinal caverns and of intercavernous connective tissue rich in elastic fibres but lacking in smooth muscle fibres as seen in human counterparts. This description shows similarity to that of the corpus cavernosum urethrae in pig (ENDO, 1954). The human corpus cavernosum urethrae is composed of vein plexus but in a dog it is a mere aggregation of caverns with single-row endothelial cells. The caverns are small in size at the central part but become larger as the periphery is approached.

The corpus cavernosum glandis or the SCHMALTZ's so-ealled gland bulb is a formation peculiar to canine penis. It consists of caverns arranged longitudinally in a rather strongly developed connective tissue layer, which appear arranged almost in a single row in a cross-sectiona cavernous body filling up the circumference of the glans penis in the 
form of a cylinder. In short, it may be called the corpus cavernosum cylindricum glandis. This body is also utterly devoid of smooth muscle fibres. It is lined with annular, rather loosely arranged, connective tissue layer, which again touches the penis bone and the corpus cavernosum urethrae on its inside. The branches of a. et $n$. dorsalis penis are found running through this connective tissue layer, especially on both the lateral sides of penis bone, but not the v. dorsalis penis. The latter probably runs to the proximal part of the cylindrical cavernous body, as an extension of the caverns.

The circumference of the corpus cavernosum cylindricum is lined with an annular collagenous layer, which corresponds to the tela submucosa, and containing rather thick blood vessels and small nerve bundles. The lamina propria mucosae of glans penis immediately covering it is composed of a minute fibrous connective tissue and sends out rather regularly arranged small papillae into the surface epithelium. In rarer cases, however, the papillae are large and ovoid. The epithelium is a non-cornified stratified flat epithelium and is considerably thick. The epithelial cells are small-sized and nucleated and belong to mucous epithelium in nature.

The penis bone at the tip of the glans goes over into a special columnal body consisting of very peculiar stellar or fusi-form connective tissue cells arranged densely, containing small blood vessels and small nerves and in hardness reminding of cartilage, with its circumference covered with a periosteum extending from the penis bone. When the cylindrical cavernous body disappears from sight, another cavernous body with a cavern formation similar to that of the corpus cavernosum urethrae comes up in its place, but it is far weaker in size and structure and tapers off toward the tip of the glans penis. The cavern formation in this part is marifest only in the corpus cavernosum urethrae and its circumference is bounded off from the lamina propria glandis by a connective tissue rich in small blood vessels, especially, small veins and small nerves. No noteworthy change in the structure of the epithelium and the formation of papillae into it is obeerved in the tip part of the glans penis.

What is of interest in the praeputium of a dog penis is the fact that its inner plate consists entirely of mucous membrane, which is not the case in the human praeputium. The outer plate is of a haired skin having a large quantity of bristles. The epithelium of the inner plate is a stratified flat epithelium far thicker than that of the glans, consisting of much larger epithelial cells than in the latter. However, the epithelium on the ventral side is formed of smaller cells nearly as small as in the glans epithelium. The epithelial cells are also nucleated and 
the epithelial surface does not cornify. That is, this epithelium is a genuine mucous membrane epithelium in nature.

The lamina propria mucosae under the epithelium comprises a part consisting of fibrous connective tissue and another consisting of reticular connective tissue. The quantitative difference between the two parts varies remarkably from $\operatorname{dog}$ to dog. In the former part, the propria grows comparatively regularly arranged small papillae as in the glans, while in the latter, lymph nodes are formed in the propria, of ten containing germ centers in them. In this part, no papillae formation into the epithelium is observed, while the epithelium here is very thin and is infiltrated by numerous lymphocytes, as the case is in the tonsilla palatina, tonsilla lingualis etc. The propria is surrounded by a tela submucosa of a loose arrangement of collagenous fibres and containing rather thick blood vessels and small nerve bundles. Neither glandular formation nor smooth muscle fibres are found in the inner plate of the praeputium.

The outer plate of the praeputium is separated from the inner plate by the fascia penis which consists of an external annular and an interior longitudinal connective tissue layers. These layers also show remarkable difference in relative development by individual dogs. The epidermis consists in a very thin stratified flat epithelium covered by a deciduous stratum corneum, as in common haired skin, and no papillae formation into it from the corium is observable here. The follicle glands formed around the hair follicles having the tufts growing in patches are not well developed. It is of interest that all sweat glands in this part are apocrine in nature, excellently developed and spread out in a large area around the follicles, in the lower part of the reticular layer of the corium and the subcutis including the adipose tissue. In this skin also no smooth muscle fibres are found, as in the human counterpart.

The sensory nerve fibres running into the penis are medullated fibres from the $n$. dorsalis penis originating in the $n$. pudendalis. This nerve contains also many unmedullated vegetative fibres. The vegetative fibres supplying the penis, however, mostly have their courses in the plexus corporis cavernosi penis originating in the $n$. hypogastricus. The periarterial plexus along the blood vessels, in particular, a. dorsalis penis is of course vegetative in nature. The vegetative fibres mostly spread out in the vascular walls and the cavernous bodies.

There is a special interest in the study of the sensory innervation of the canine penis, for its structure is considerably different from that of man or a pig. In particular, the praeputium is very peculiarly constructed, the inner plate being composed of a typical mucous membrane and the outer plate of ordinary haired skin, so that it is easy to 
infer that the former is very rich in sensory fibres, while the latter, lacking the special composition of the skin usually covering the external genitals, is rather poor in sensory innervation.

The plexus corporis cavernosi penis is distributed widely in the corpus cavernosum urethrae and corpus cylindricum glandis in the foremost part of the canine penis, and vegetative fibres are also distributed to varied extents in the cavernous body in the tip of the glans and the lamina propria of the glans and the praeputium. The termination of these vegetative nerve fibres is always represented by a cord-wise arrangement of net-work of minute nerve fibrils, or the STÖHR's so-called terminalreticulum, as it has been established by many studies on the subject at this laboratory. In the cavernous bodies, this reticulum very of ten penetrates as far as the endothelial cells, running in contact with them. Such terminal cords are also in conspicuous formation along the blood vessels, especially, the arterial walls, around the apocrine sweat glands and the hair follicles of the praeputium. The terminalreticulum always stands in tactile control over the supplied cells and in no case intrudes into the cell bodies to effect cytoplasmatic anastomosis, a finding in good agreement with the results of many other studies at this laboratory.

It has been long known that there are special sensory terminal bodies in existence peculiar to the external genital organs and never to be found outside them. The so-called genital nerve bodies and the small-sized PACINIAN bodies belong to such special bodies, of which the former have been deemed the receptor apparatus of sexual sensation par excellence. A few reserchers have opined that some MEISSNER's touch bodies are also present in external genitals, but in concurrence with the observations by YAMADA (1951) and ENDO (1954) of this laboratory, I have been led to deny the existence of such bodies here in the canine external genitals, too.

The genital nerve bodies were classified into three types by IAMADA (1951) in his study on the innervation of human clitoris and praeputium, and it was found that the labium minor (IKUI, 1949), the scrotum (HOTTA, 1952) and the papilla and the areola mammae (SUGA, 1951) contain his types $I$ and II but not type III. In the pig penis also the above three types were found and the type II was further subdivided into two subtypes by ENDO (1954). Now, the genital nerve bodies in my sections of the foremost part of the canine penis were found to be somewhat different from those in man and pig in form and structure and could be classified only into types I and II. These genital bodies could be found also in the inner, but not in the outer plate of the canine praeputium, apparently due to the fact that the latter part is 
covered with ordinary hairy skin. This deficiency must be also apparent in the canine scrotum under the same rearon.

The most peculiar characteristic of the genital nerve bodies in the canine penis is that the inner bulb is filled with far more numerous special nuclei than in man and pig. The inner bulb, in my canine specimen as in other cases, origtinates in SCHWANN's sheath and is syncytic. in nature, and in response to external stimuli effects special internal secretion, which in turn stimulates the sensory nerve termination within the bulb. The genital bodies are encased in a connective tissue capsule each, which is, however, rather poorly developed, so that in many cases no capsule is formed at all.

The genital nerve bodies type I are found in the glans and more rarely in the inner plate of the pracputium, always imbedded in the lamina propria of the glans and the connective tissue layers lining it and the connective tissue layers within and outside the corpus cavernosum cylindricum, but never in the papillae of the glans and the inner plate of the praeputium, because the papillae here

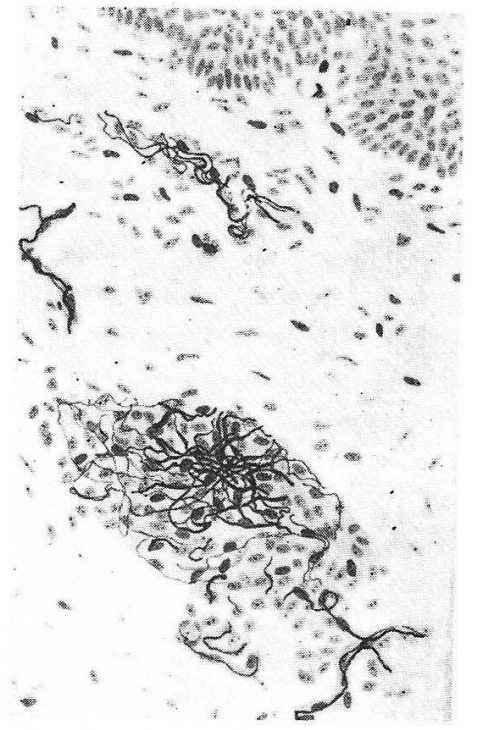

Fig. 3. A ovoid genital nerve body Type I seen in lamina propria of a canine glans penis. Same staining. $\times 400$, reduced to $1 / 2$.

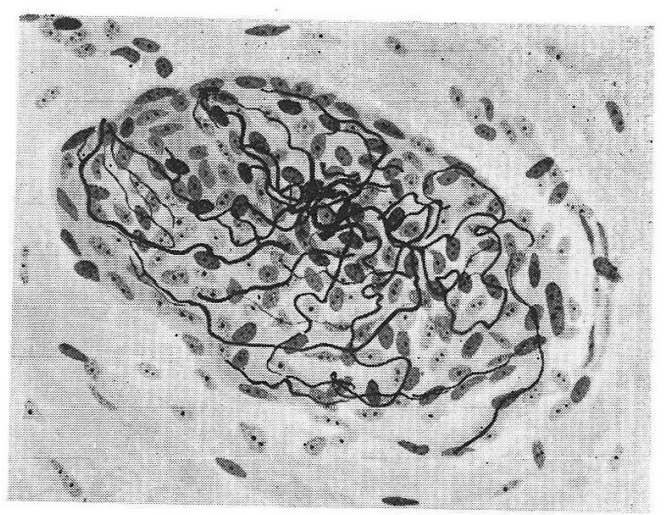

Fig. 4. A ovoid genital nerve body Type I found in the tubular corpus cavernosum glandis of a dog. Same staining. $\times 500$, reduced $2 / 3$. 
are too small for accommodating such bodies, in comparison with the papillae in human and pig penis. Interestingly enough, the genital bodies of this type are far poorer than those in human and pig penis in quantity.

A genital nerve body type $\mathrm{I}$, as shown in Figs. 3 and 4 , is formed by two or three thick medullated but demyelinated fibres running into an ovoid or spherical capsulated inner bulb containing very numerous irregularly arranged special nuclei, and then repeatedly ramifying and anastomosing, to end in a complex glomerular arrangement in the entire area of the inner bulb. The fibres run peculiar ansiform courses showing marked change in size in forming the glomerular termination.

The genital bodies type II are found in the canine glans in a far smaller number than those of type I. But they are found more frequently in lamina propria or tela submucosa of the inner plate of the praeputium, especially near the tip thereof. Some of the specimens of this type are round or ovoid as those of type $I$, but in many cases they are drawn out in very long cylinders. Such elongated forms are especially often found in the inner plate of the praeputium. This type II was subdivided by ENDO (1954) into two subtypes in pigs, but in my canine specimen I could not distinguish a second subtype provided with many terminal corpuscles, all of the bodies of this type being formed by thick unmyelinated sensory fibres running into capsulated inner bulbs, to end in branched terminations after comparatively simple ramifications, as in the same type of bodies in man. The canine specimens are, however, characteristic in that they contain very numerous special

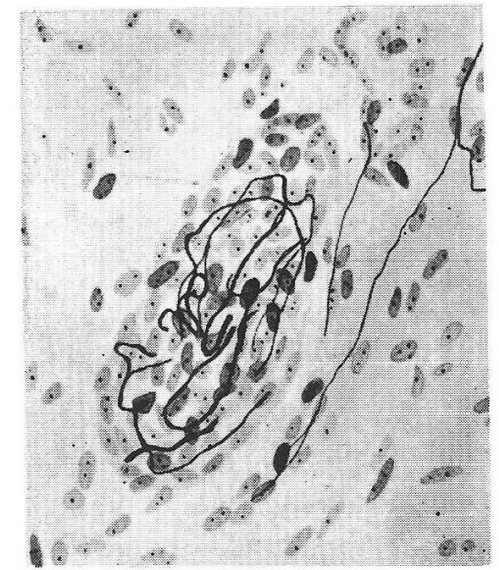

Fig. 5. A ovoid genital nerve body Type II seen in the same place as in the former. Same staining. $\times 400$, reduced to $2 / 3$. nuclei in thoir inner bulbs, as was the case with those of type I.

Figs. 5 and 6 show genital nerve bodies type II of ovoid shape found in the strong connective tissue of the corpus eavernosum eylindricum in a canine glans, while in Fig. 7 is shown a body of the same type but very much elongated and cylindrical in shape formed in the lamina propria of the inner plate of the praeputium composed of fibrous connective tissue. In these bodies the nerve elements are conspicuous for their quite peculiar winding and marked change in size during their courses. 


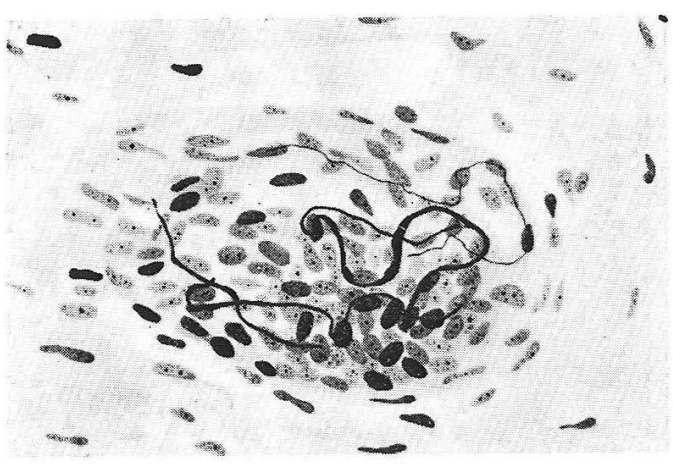

Fig. 6. Ditto. Same staining. $\times 600$, reduced to $1 / 2$.

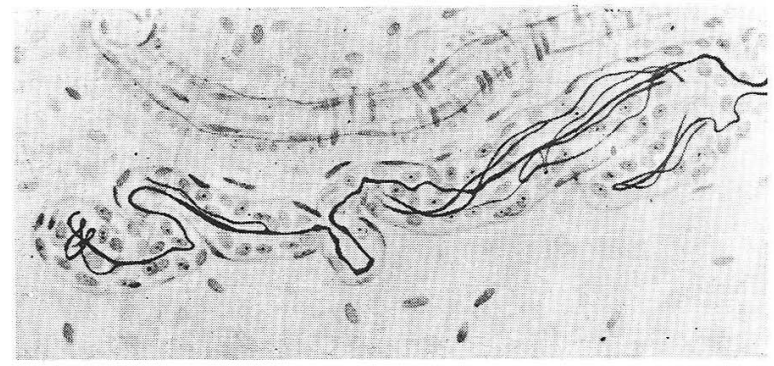

Fig. 7. A long tubular genital nerve body Type II formed in the fibrous connective tissue propria of the inner plate of a canine praeputium. Same staining. $\times 400$, reduced to $1 / 2$.

Beside the above two types of genjtal nerve bodies, the following terminations are found existing in the canine glans penis: 1. PACINIAN bodies. These are extremely small, both in size and number, and are chiefly found alongside the rami of $n$. dorsalis penis that proceeds along both sides of the periosteum of the penis bone. They are composed of a few lamellae and a rather large inner bulb containing numerous special nuclei. 2. Branched terminations abundantly found in the lamina propria of the glans penis, comprising simpler (Fig. 8) and more complex types. The nerve branches in these terminations always run very irregular winding courses before ending sharply or bluntly, mostly close to the epithelium. None of them were found to penetrate further into the epithelium to form intraepithelial fibres. These terminations orjginate sometimes in thick medullated fibres but sometimes also in finer medullated fibres. 3. Terminations found in the special connective tissue column extending from the tip of the penis bone. These originate in the thin medullated fibres contained in the regetative nerve bundles accom- 


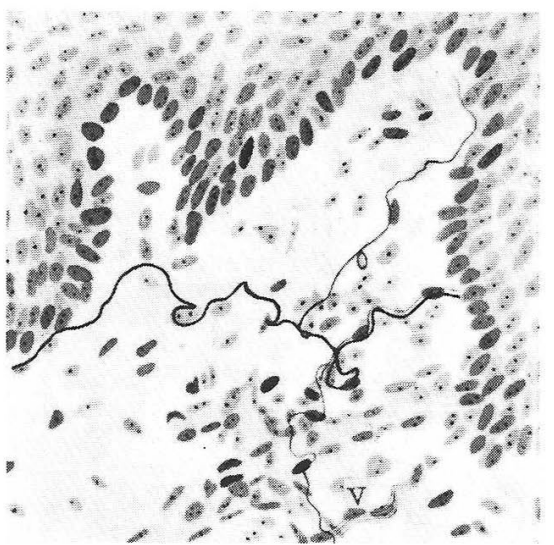

Fig. 8. Simple branched sensory termination found beneath the epithelium of a canine glans penis. $\mathbf{v}$ fine vegetative nerve fibres. Same staining. $\times 500$, reduced to $2 / 3$.

either simple or complex, but such extremely complex branched terminations as found by SETO (1942) in human urethra have never been observed here in the canine urethra. Some unbranched terminations have been often found as well. Fig. 9 shows a simple branched termination found in the subepithelial propria of a canine urethra, and it may be noted that all the terminal branches show marked change in their size during their peculiar winding courses and always end sharply. Fig. 10 illustrates a rather complex branched termination, of which the terminal branches show as much change in size and winding in their courses but end sometimes bluntly, as well as sharply, after running peculiar ansiform courses.

In human urethra, intraepithelial fibres of considerably complex structure have been found (SETO 1942 and NOBUTA 1949), but in a canine as well as in a pig (ENDO 1954) urethra only a very limited number of intraepithelial fibres of the simplest unbranched type could panying the blood vessels entering this special column. The fibres, after losing their myelins and sending out several branches at long intervals, end in branched terminations widely distributed in the special connective tissue. The fibres are smoothsurfaced, showing little change in size and always end sharply.

The lamina propria mucosae of the canine urethra is comparatively rich in sensory fibres. Their terminations are of branched type, the branches always showing change in thickness and peculiar winding during their courses. The terminations are

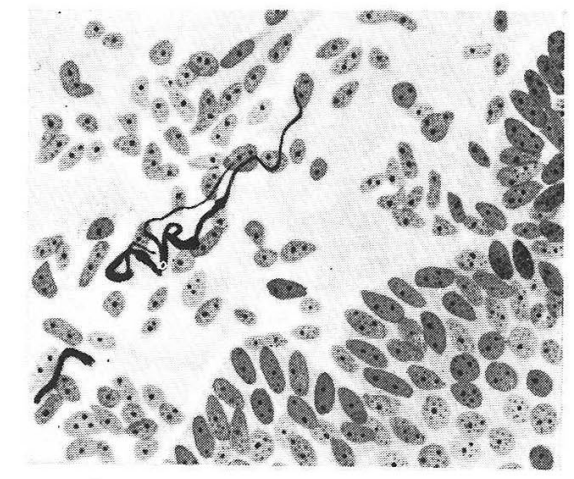

Fig. 9. A simple branched sensory termination found in lamina propria of a canine urethra. Same staining. $\times 400$, reduced to $2 / 3$. 


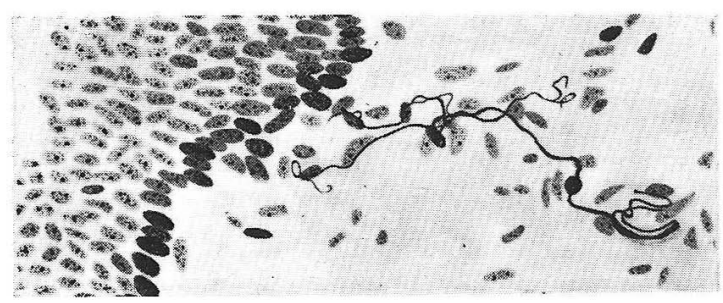

Fig. 10. A Comparatively complex branched sensory termination seen in lamina propria of a canine urethra.

Same staining. $\times 600$, reduced to $1 ! 2$.

be found (Fig. 11). Since no urethral glands were found to exist in a canine urethra, it follows that no intraepithelial fibres running into the gland ducts, as found in human urethra, can exist here.

Seeing that the inner plate of the praeputium is a mucous membrane in nature, it may be easily surmised that it is well provided with sensory fibresfar better than the outer plate. In fact, the lamina propria composed of fibrous connective tissue, especially of the distal extreme, contains a rather large quantity of genital nerve bodies type II and a smaller quantity of type I, and numerous branched terminations

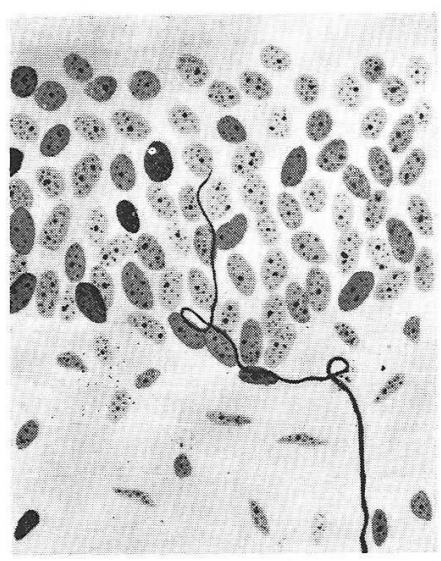

Fig. 11. An unbranched intraepithelial nerve fibre. Canine urethra. Same staining. $\times 600$, reduced to $2 / 3$.

are found beneath the epithelium,

sometmies of simple type, but in many cases of considerable complexity (Fig. 12). No intraepithelial fibres, however, may be found here. Very small-sized PACINIAN bodies are very often found in the connective tissue constituting the outer layer of the inner plate. Thus it may be pointed out that the development of sensory terminations in the inner plate is very remarkable in such a lamina propria composed of fibrous connective tissue, while it is much poorer in the part where subepithelial lymphatic tissue is formed.

The sensory fibres running into the outer plate of the praeputium are mostly represented by sensory hair nerve fibres, as in other parts of the hairy skin. The sensory fibres running as far as the papillary layer beneath the epidermis are severely limited in number and end in nothing more complex than unbranched or simple branched terminations. The scnsory hair nerve fibres end in the special connective tissue 


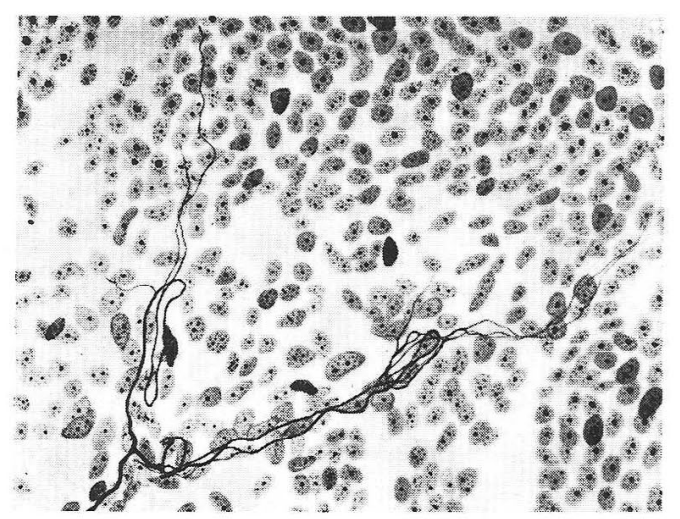

Fig. 12. Complex branched sensory termination found in the fibrous connective tissue propria of the inner plate of a canine praeputium. Same staining. $\times 500$, reduced to $3 / 2$.

terminal territories in the follicle necks, which in this part are always in the form of SwTO's hair-nerve shields, so that the sensory terminations formed in these territories are generally simple, of bush-like, of fencelike (Fig. 13) or sometimes of non-descripi shape.

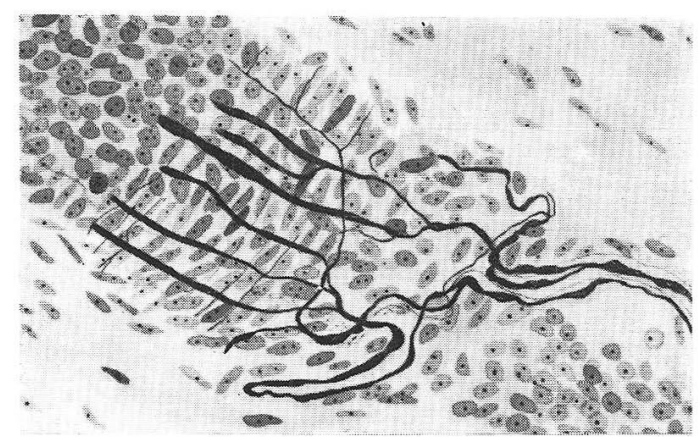

Fig. 13. Simple fence-like termination of sensory hair nerve fibres found in the outer plate of canine praeputium. Same staining. $\times 400$, reduced to $2 / 3$.

It has been already proved that a part of the sensory fibres from the $n$. dorsalis penis goes over into small-sized PACINIAN bodies, in man as well as in other animals, and in a canine penis, the existence of such bodies is very conspicuous, too, especially in the subcutis of the outer plate of the praeputium.

These may be divided into two types by their form. The one is composed of numerous lamellae and a small inner bulb containing a small 
number of special nuclei, the nerve fibre running into the bulb ending without branching in most cases (Fie. 14), while in the other, the inner bulb is much larger and very rich in special nuclei, but the lamellae are very limited in number, and the nerve fibre running into the bulb mostly ends in a branched, but sometimes also unbranched termination. (Fig. 15). Anyhow, it is worth of special attention that there are found PACINIAN bodies also in the praeputium of a canine penis, and that these are of extremely small size.

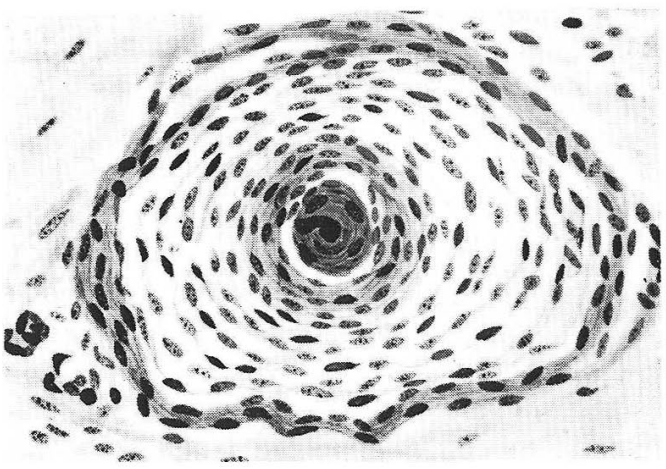

Fig, 14. A small PACINIAN body provided with many lamellae found in the connective tissue outer layer of the inner plate of a canine praeputium.

Same staining. $\times 400$, reduced to $1 / 2$.

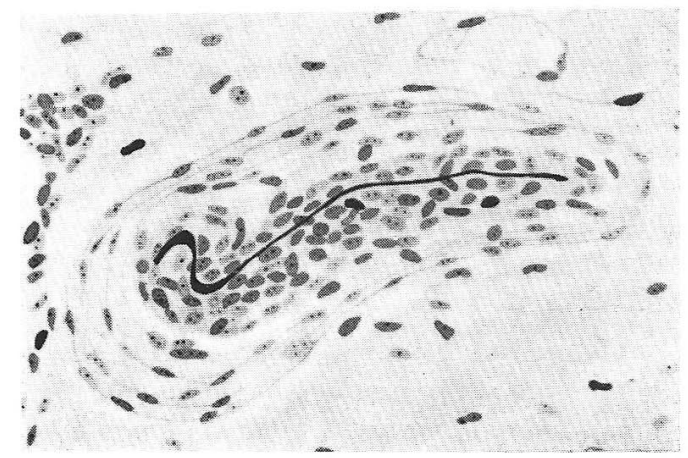

Fig. 15. A small PACINIAN body provided with many specific cell nuclei in its inner bulb found in the subcutis of the outer plate of canine praeputium. Same staining. $\times 400$, reduced to $1 / 2$.

\section{Summary.}

In the glans penis of a dog there is a penis bone covered with a 
tough periosteum and succeeded by a special connective tissue column at the farther end. The penis bone and the corpus cavernosum urethrae is enwrapped in a connective tissue layer containing aa. et $\mathrm{nn}$. dorsales penis, around which there is my so-called corpus cavernosum cylindricum glandis. Corpus cavernosum apicis glandis takes the place of the former cavernous body at the tip of the glans.

The urethra in glans penis is composed of a stratified columnar epithelium and a fibrous connective tissue propria and has no urethral glands. Corpus cavernosum urethrae is full of longitudinal caverns and contains no smooth muscle fibres. Corpus cavernosum cylindricum glandis is composed of a tough connective tissue and longitudinal caverns running in it in a row, and is devoid of smooth muscle fibres. Around this cavernous body there is a connective tissue layer corresponding to the tela submucosa and the lamina propria composed of minute fibrous connective tissue around it forms minute papillae into the epithelium glandis, which is represented by an uncornifying stratified flat epithelium of mucous nature.

The inner plate of the canine praeputium is a mucous membrane, while its outer plate consists of ordinary hairy skin. The epithelium of the inner plate is represented by a mucosal stratified flat epithelium consisting of larger cells than those of the epithelium of the glans and is thicker than the latter. The lamina propria comprises a part consisting of fibrous connective tissue and another consisting of lymphatic tissue. Small papillae are formed in the former part. Neither gland formation nor existence of smouth muscle fibres is observed in the inner plate of the praeputium. The epidermis of the outer plate of the praeputium is composed of a thin cornifying epidermis and few, if any, papillae are formed into it. Hairs grow in tufts, but the development of the follicle glands is poor. Sweat glands are always apocrine in nature and are extremely well developed. No smooth muscle fibre is found in the outer plate, either.

The vegetative nerve fibres running into the canine glans penis mostly spread out into the corpus cavernosum urethrae and corpus cavernosum cylindricum, but some are conspicuously found distributed in the corpus cavernosum apicis glandis, the lamina propria of the glans and the praeputium. The termination of the vegetative nerve fibres is always represented by the STÖHR's terminalreticulum in canine penis also, reaching as far as the endothelial cells of the caverns in the cavernous bodies. The terminalreticulum is also conspicuously proved around the apocrine and follicle glands.

As corpuscular sensory terminations existing in the canine penis, we may cite the genital nerve and the PACINIAN bodies. Of the former, 
only the types I and II are observed, the type III being utterly absent. They are found only in a small number in canine penis, incomparably fewer than those in man and pig. Their inner bulbs are characteristically filled with numerous special nuclei. Such genital bodies are seen in the lamina propria of the glans, the connective tissue around it, the corpus cavernosum cylindricum and the inner plate of the praeputium. They are found neither in the papillae nor in the outer plate of the praeputium.

Genital nerve bodies type I are found mostly in the glans penis and more rarely in the inner plate of the praeputium. In a body of this type, two or three demyelinated thick fibres run into the ovoid or spherical capsulated inner bulb, repeatedly undergo ramification and anastomosis and form complex glomerular terminal formation in the whole area of the inner bulb. The genital nerve bodies type II are found in the inner plate of the praeputium in a number, are spherical or ovoid, but very often also elongated cylindrically in shape, and contain inner bulbs in which the sensory fibres end in simple branched terminations. In both types, the nerve fibres show peculiar winding and marked change in size during their courses.

Besides, in the glans penis there are found a very small number of small-sized PACINIAN bodies along the branches of the $\mathrm{n}$. dorsalis penis and a large number of simple and complex branched terminations in the lamina propria glandis. In the latter, the terminal branches run irregular winding courses and end subepithelially in sharp points, but never penetrate further into the epithelium to form intraepithelial fibres. Often some branched terminations of fine fibres are found in the connective tissue column extending from the tip of the penis bone.

The lamina propria of the urethra in glans penis contains a rather large number of sensory terminations, all in the form of branched endings, which may be classified into the simpler and more complex types, but no such extremely complex terminations as found in human urethra can be observed in the canine urethra. Rarely, some intraepithelial fibres are found here, but these are always of simple unbranched type.

In the inner plate of the praeputium, especially in its connective tissue propria, may be found, beside a comparatively large number of genital nerve bodies type II and a small number of ditto type I, a large quantity of branched terminations. No intraepithelial fibres, however, are found here, too. Not rarely, some small-sized PACINIAN bodies are found in the periphery of the mucous membrane. The distribution of sensory nerve fibres is very limited in the lymphatic tissue propria. 
The sensory innervation of the outer plate of the praeputium is almost limited to the sensory hair nerve fibres, the sensory terminations ending in the papillary layer being found only very rarely and the terminal formations of these being of the very simplest type. The terminal areas of the sensory hair nerve fibres being represented by the SETO's so-called hair-nerve shields, the nervc terminations are always of simple structure, bush-like, fence-like or indefinite in shape. Smallsized PACINIAN bodies, which can be classified into two types in form, are found here and there mostly in the subcutis.

\section{內 容自抄。}

犬陰茎先端部内に見られる知覚神経終末の中で小体様終末に属するもの は陰部神経小体とPacini 氏小体とである。

陰部神経小体は人及び豚の夫と比すれば甚だ少量と存し，其内棍が甚だ 多量の特殊核で満されている事が特異的であり, 之進入する知覚線維の 終末状態に依り第I型及び第II型小体とに分けられる。即ちI型では内棍 全領内に複雑な糸㲑状終末の形成が，II 型では専ら内棍中尖部に単純な分 岐性終末の形成が見られる，I型は專ら亀頭の固有膜及び其内方飞存する 余の所謂亀頭円筒海綿体の内外，又稀飞包皮内板内飞存し，II 型は專ら包 皮内板内飞形成される.

犬陰兴龟頭内に見られる知覚終末としては以上陰部神経小体の外に, 甚 だ小型のPacini 氏小体が極く少荲に陰茎背神経枝に沿って, 又患頭固有 膜には単純性及び複雑性分岐性終末が多量に発見される。此分岐性終末で は各終末枝は不規則な迁曲走行の後, 多くは上皮下飞尖鋭状に終る。然し 上皮内線維飞移行する事はない。

尿道の固有膜内には比較的多量の知覚終末が存在する。終末様式は専ら 分岐性終末で表わされる。，之性稍々複雑性を示寸ものもあるが，人尿道 飞見られる様な甚だ複雑な分岐性終末の如きは認められない，上皮内線維 も稀飞発見されるが，多くは非分岐性を示す。

包皮内板注純粘膜性であり，外板は一般外皮性である事は甚だ興味深い. 内板の固有膜は線維性結締織から成る部と淋巴組織から成る部と飞分けら れる。前者内Vは比較的多量の陰部神経小体 II 型と小数の I 型の外, 多量 の分岐性終末の存在を見る. 然し上皮内線維は存在しない. 粘膜の周辺飞 は稀ならず小型のPacini 氏小体が認められる，反之淋巴織性固有膜内と は知覚線維の分布は甚だ劣勢である。

包皮外板に対する知覚線維は殆んど総て知覚性毛髮神経線維で表わさ 
れ，反之乳頭層内飞形成される知覚終末は甚だ少く，其終末様式も極めて 単純である。知覚毛髮線維の終末領は專ら毛髮神経楯（瀬戸）で表わされ る。それ故終末様式も単純な叢状終末, 䒽状終末又は不定型終末で表わさ れる。尚招皮下組織内とは形態上， 種と区別される小型のPacini 氏小体 の存在を見る。

\section{References.}

Dogiel: Arch. mikr. Anat. 41 (1983). S. 585. - Endo: Arch. hist. jap. 6 (1954). P. 313. - Ferrarini : Anat. Anz. 29 (1906). S. 15. - Hotta: Arch. hist. jap. 4 (1952). P. 1. - Ikui : Tohoku Igaku Zassi (Jap.) 39 (1949). P. 104. Kölliker: Handbuch der Gewebelehre. Pd. 3. Leipzig, W. Engelman, 1902. S. 580. - Krause : Z. rat. Med. 28 (1866). S. 86. Cited by Stöhr. - Matsuda : Kaibougaku Zassi (Jap.) 8 (1935). P. 532. - Müller u. Dahl: Dtsch. Arch. klin. Med. 107 (1912). S. 113. - Nobuta: Tohoku Igaku Zassi (Jap.). 39 (1949). P. 5. - Ohmori: Z. Anat. 70 (1924). S. 347. - Retzius : Internat. Monatschr. Anat. u. Physiol. 7 (1890). S. 323. - Schmaltz: Handbuch der vergl. mikrosk. Anatomie der Haustiere. Bd. 2. 1911. S. 438. - Sclavunos: Anat. Anz. 9 (1894). S. 42. - Seto : Arb. Anat. Inst. Sendai. 22 (1939). S. 1; 25 (1942). S. 99. Stöhr: Mikr. Anat. des vegetat. Nervensystems. Berlin, J. Springer, 1928. S. 164. - Suga: Tohoku Igaku Zassi (Jap.). 54 (1951). P. 163. - Tello: Trav. Lab. Rech. Biol. Madrid. 28 (1932). P. 1. - Wada: Tohoku Igaku Zassi (Jap.). 39 (1949). P. 73. - Yamada: Tohoku J. exp. Med. 54 (1951). P. 85 . 